\title{
Rule and Representation: Transformations in the Governance of the Water Commons in British South India
}

\author{
DAVID MOSSE
}

$\mathrm{I}_{\mathrm{N}}$ offers fresh insight into the nature of colonial and postcolonial state power by clarifying the complex relationship between rule and representation. He demonstrates how policy universals, which appear as rational abstractions separate from the social order they govern (as the rule of law, private property, or the economy), can be shown to be historically grounded in particular interests and events, contingencies, violence, and exclusions. The apparent logic, universality, and coherence of these ideas, as well as the expertise and rational design that they call forth, are not inherent, but are produced through the messiness of contingent actions which succeed in concealing social practice by effecting the separation of ideas and their objects: a bifurcation of representation and reality that is characteristic of the modern world. Mitchell addresses a key dilemma in the study of colonialism: the dramatic social and environmental changes of the nineteenth and twentieth centuries cannot be made sense of in terms of the rationalizing principles of colonial rule, yet imperial systems of knowledge have had a lasting impact on social and physical systems.

Drawing on these ideas, this article will illustrate how colonial rule in India did not involve the assertion of the rule of law, administrative code, or science over kingship, community, or nature. The principles of property, revenue, or law did not constitute a preformed conceptual structure of rule imposed from the outside, but were worked out through compromise and contingent action in a variety of areas such as altered revenue demands, property disputes, engineered technology, and court decisions-not as the application of policy principle, but as selective, arbitrary, local actions and exceptions which wrought change not by their own logic, but through the rupture and contradiction that they effected in the existing social and political systems (Mitchell 2002, 77).

David Mosse (dm21@soas.ac.uk) is a Reader in Social Anthropology at the School of Oriental and African Studies, University of London.

I am grateful to the Ford Foundation (New Delhi) and the Economic and Social Research Council (grant no. 1320273065) for supporting the research undertaken during 1993-96 and to M. Sivan for field assistance.

The Journal of Asian Studies 65, no. 1 (February 2006):61-90.

(C) 2006 by the Association for Asian Studies, Inc. 
The ruptures that are of particular interest here are those with environmental consequences. Specifically, the article will focus on the effect of colonial rule on decentralized water-resources systems in nineteenth-and twentieth-century south India. Rethinking bureaucratic power is especially relevant here because an influential stream of Indian environmentalist thought locates the roots of present-day drought vulnerability and deforestation precisely in British colonial power, its assertion of proprietary rights over the commons, its imposition of imperial science (engineering or forestry) and bureaucratic management, and the consequent erosion of complex indigenous resource systems (Gadgil and Guha 1992, 1995; Agarwal and Narain 1997). It is true that there are parallel lines of argument that maintain that much of what is taken as indigenous or as tradition or community in "standard environmental narratives" (Madsen 1999,2 ) does not in fact stand apart from the state, but was administratively invented as the preferred means for the exercise of governmental strategies (see, for example, Mosse 2003, chap. 8; Li 2002; Sinha, Gururani, and Greenberg 1998; Sundar 2000). However, in neither environmentalist narratives nor their constructivist revisions is the agency of the state in question; neither examines the relationship between rationalizing self-representations and the messiness of practice that accompanies or precedes the ideas and technologies of rule (Mitchell 2002).

Recent work has questioned the idea of the state in India as a unified source of intention and power and has shown claims about bureaucratic power to be as problematic as those about authentic communities (Fuller and Harriss 2000). The forester's or engineer's scientific plans are constantly reworked by local rights, and state power is but a fragile representation sustained by concealing informal process and compromise (Sivaramakrishnan 1999, 244; Li 1999). Mitchell encourages us to go further and explore the contingent world of relations, materiality, hybrid action, or violence, not only as that which is concealed by policy intent but also as the origin of universal rational principles of rule-property, law, and science. He directs our attention to the arrangements put in place that made it possible to abstract and separate principle and practice, ideal and actual, conceptual and material, science and nature, state and community, ancient past and corrupt present, and thus establish a domain of expert rule that stood apart from the local, arbitrary, and contingent world of relations that is in fact its origin $(2002,77-78,100-101)$.

This article begins such an effort by exploring the relationships masked by representations of colonial power in the field of irrigation. It questions the transformative power of the colonial state in India in relation to water resources by locating the noncolonial origins of colonial change, discerned not from bureaucratic or engineering intention and impositions, but from the response of preexisting systems to the contingent and hybrid actions of a British administration. These compromises of rule produced a multilayered and decentered form of state continuous with pre-British forms and experienced as overlordship of a variety of kinds: of kings, zamindars, temples, caste chiefs, and trader/bankers, as well as the British government.

Drawing from oral histories and archival evidence, this article analyzes the shifting nature of transactions around irrigation and the contradictions that emerged between different rationales of governance and resource management as well as the economic and environmental consequences of these contradictions. It provides a view from the edge of empire, from the warrior-controlled southern plains, which were incorporated into British administrative systems only late and incompletely and where precolonial institutions have left a strong imprint on social memory and ritual as well as in the archive. 


\section{A Tank-Irrigated Landscape in the Southern Plains}

The coastal plains of southern Tamil Nadu are etched with a complex pattern of reservoirs and irrigation channels, easily overlooked at ground level but visible momentarily during a monsoon overflight and captured on the huge blueprints and tracings unrolled over the tables of the district public-works departments. My concern, however, is with the historical and political processes of landscape associated with the engineered flows of water across these plains, largely concealed by maps, aerial views, or satellite images. Indeed, the "painterly dimension" implied in the concept of "landscape" itself involves a way of seeing which both denies process and "privileges the 'outsiders" point of view" (Hirsch 1995, 22). ${ }^{1}$ Water involves social, political, and bureaucratic processes which, I aim to show, are woven into the history of social life and landscape in south India.

If we remain with the abstracted panoptic view for a moment longer, we see the southern Tamil plains as a region where heavy runoff (or river flow) from concentrated rainfall is diverted, captured, stored, and controlled in a large number of reservoirs, or, following early Portuguese usage, "tanks" (from tanque), formed by taking advantage of the natural depressions of the relief and erecting crescent-shaped earth dams across the drainage flow. In this way, water is literally harvested so that none drains into the Bay of Bengal. The Jesuit missionary Father Martin, in a letter from 1713, writes of a river (the Vaigai) that enters Ramnad District, "as large as the Seine," during an ordinary monsoon: " $[B] y$ the means of canals dug by our Indians, going as far as their tanks, this river is bled so much from all directions that it is lost entirely and does not arrive at its mouth, having taken several weeks to fill the numerous reservoirs to which it has been diverted" (Nelson 1868/1989, 3:241; my translation).

This is a region where, more than any other, life depends on and revolves around the control of scarce water through systems of tanks. ${ }^{2}$ Except for the peak months of the northeast monsoon, more water is lost through evapotranspiration than is gained through rainfall (Athreya, Djurfeldt, and Lindberg 1990, 56). Without the storage of water in tanks, the cultivation of rice as well as stable settlement in this semiarid region would not have been possible. Indeed, tank building represents the very earliest form of irrigation in India. Tank systems have characterized the southern Tamil region since Pandya and Chola times (ca. 750-1300) and were precursors to the development of riverine canal irrigation in the eleventh century (see Heitzman 1997; Stein 1980, 94), while in the drier plains areas such as present-day Ramnad and Sivaganga districts discussed here, tanks were developed later and continued to expand between the sixteenth and eighteenth centuries. In these districts, there are today over ten thousand tanks irrigating an estimated 530,000 hectares (in the 1960s), accounting for over 90 percent of irrigation. Most of these tanks are directly rain fed, though some receive water from the river Vaigai. The absolute and relative contribution of tanks to irrigation is far higher here than elsewhere in Tamil Nadu or India more generally, where alternative irrigation sources (canals, wells) have been available and where tank

${ }^{1}$ As Mitchell points out, the map "erases and hides the contested political, representational nature of the world it portrays," erasing signs of the power of its own making $(2002,117)$.

${ }^{2}$ Tanks are unevenly distributed in the subcontinent, being mostly concentrated in southern and central India - the coastal districts of Tamil Nadu, Andhra Pradesh, and south-central Karnataka, as well as Telangana and East Vidarbha-and northern Sri Lanka; these tanks account for nearly 60 percent of the net tank-irrigated area (Vaidyanathan 1992, 3). Within Tamil Nadu, Old Ramnathapuram (the subject of this article) has the greatest density of tanks. 
irrigation declined from 1968-69 onward, particularly in relation to well irrigation (Vaidyanathan 1992).

The hydrology is such that tanks interlinked through drainage flows form chains or "cascades" broadly oriented to follow the gentle southeasterly slope of the land from the western hills to the eastern coast and capturing the maximum amount of runoff for irrigation (Sengupta 1993, 61). These were not designed as systems, but were developed piecemeal over several centuries as antecedent works were incorporated, improved, or integrated. New tanks were added to a series, small dams or "anicuts" were used to improve supply to existing tanks, and channels were excavated to interlink them (see Ludden 1985, 53). The technical and hydrological arrangements of this irrigated landscape shaped social strategies for the allocation of water; the control of floods; and (as I will argue below) the organization of supralocal political power, which granted rights and mediated constant disputes.

Today this ancient water-harvesting system is widely regarded as being in a state of serious decline; indeed, decay has almost become its defining feature. There are good reasons for viewing this resource system as in decline: among them, the effects of increased water demand, land fragmentation, changed land-use patterns, and "encroachment" onto foreshores and channels-all to some extent related to population growth. ${ }^{3}$ Other factors include the weakening of the structures of village authority which hold irrigation systems together or make cooperative water management possible, reflected in changed land-holding patterns, especially land transfers from upper castes to lower castes or to landholders outside the village (Janakarajan 1997; Mosse 2003, chap. 6). Moreover, in the absence of regular maintenance, tanks and their supply channels, which have been "impounding silt for centuries," will simply disappear (Krishnaswamy 1947, 444). In ancient structures, the tank bed can be seen to have risen so as to bury old sluices (Davison-Jenkins 1997, 68). Where tanks are interlinked as chains, the amount of siltation is affected by a tank's position in the chain, some tanks at the top of the chain acting as silt traps (Krishnaswamy 1947). The risks of disregarding the maintenance of tank irrigation are well understood, though rulers have always prioritized new investments which generate political capital, even when the upstream engineering works involved reduce supply to the downstream plains tank systems. Finally, in recent decades, the increase in groundwater exploitation (part cause and part effect) has accelerated the neglect of tank structures, shifting their function from surface storage to groundwater recharge. ${ }^{4}$

While regarded as being in a state of decline, vulnerable and eroded tank systems are also threatened "indigenous spaces" that form part of an idealized precolonial past, captured in images of the environmentally sustainable village community mentioned above (Agarwal and Narain 1989, 1997). Defined in opposition to the colonial and

${ }^{3}$ Some research suggests that tanks are particularly vulnerable to the effects of increasing population density and that a direct relationship exists between population density and tank development. For the princely states of Mysore and Hyderabad, for example, M. von Oppen and K. V. Subba Rao (1980a, 1980b) identify a measurable relationship between the two variables. Specifically, they argue that when the population density passes the level of around 60 persons per square kilometer, the density of tanks increases to a maximum when the population density is 220 persons per square kilometer, dropping thereafter. Von Oppen and Subba Rao, however, find no statistically significant relationship between tank density and population in former British government-administered districts. T. Shah et al. argue that today population densities make tanks inefficient $(1999,7)$.

${ }^{4}$ This is especially true of Karnataka, where, according to one study, 44 percent of all borewells are found in or around tanks, which may recharge wells within a radius of one to five kilometers (Thippaiah 1998). 
contemporary state, they are tropes in an environmentalist critique of the modernist development state (colonial and contemporary) whose administrative order and proprietary incursions into the commons are judged as the principal force behind the demise of village traditions and sustainable resource systems, including ancient "indigenous water-harvesting systems." These narratives produce picturesque landscapes-idealized spaces with the timeless fix of a painting (not so different from the maps and engineering blueprints) that conceal political and social processes underlying tank systems while handing to colonial power its rationalizing representation of engineering science and irrigation bureaucracy. It is against the grain of these narratives that the history of water in the southern plains must be written.

\section{The East India Company, the Permanent Settlement, and Irrigation Disarray}

In relation to such ideal landscapes, tank systems have always been in a state of decline. The East India Company officers who consolidated British authority over the southern districts of Tamil country in the late eighteenth and early nineteenth centuries describe tanks as being in a parlous state. "I had [the] opportunity," wrote one,

as I progress through the country, of witnessing the wretched state in which the tanks] are at present-most of them could not have been repaired for many, many years and the consequence has been that large tracts of land have remained uncultivated for want of a regular supply of water. The inhabitants of every village I passed begged that I would look at their tanks and asked how it was possible for them to increase the cultivation, or indeed to cultivate at all, in the condition in which they then were. In the country a large part of revenue is from wet land, if therefore the source from whence it arises be neglected a diminution of revenue most naturally follows

(TNSA, collector of Madurai, R. Peter, to Board of Revenue, August 19, 1816, Madurai District Records, vol. 1164, pp. 17-18)

The unconcealed concern for revenue prompted the Company to undertake more systematic inquiry. Its late eighteenth-century surveys recorded up to 30 percent of all tanks as "unusable" (Lardinois 1989, 24-25, 38-43). But, Company officers also had an ideological ax to grind. They viewed the deterioration of what they regarded as an ancient and impressive irrigation system as "melancholy proof of the ruinous effects of an uncontrolled native management" (TNSA, diary of the superintendent of tank repairs and water courses for the month of January 1801, B/R [XIV] Misc., vol. 216) - testimony to the moral and administrative disorder of the lawless and despotic regimes which they had come to replace. These officers were the first to put into place a representation of tanks as part of the noble tradition of the ancient community eroded by contemporary exploitative rulers. And from this damaged landscape, they read justification for the extension of a British rule of order and property.

The early colonial project involved the demilitarization of former warrior kingdoms, the consolidation of power through the selective allocation of rights in property, and the extraction of a punitively high tribute. ${ }^{5}$ In Ramnad and Sivaganga this took the form of a "permanent settlement" in which selected Maravar-caste warrior-rulers

${ }^{5}$ By 1792, in Ramnad, British military successes left the warrior chiefs, called "poligars," disarmed and facing tribute demands double that of a decade earlier (Rajaram Row 1891). 
were instituted as holders of proprietary estates, or zamindaris; were required to pay a fixed tax to the government; and were expected to profit by reaping the rewards of investment in the region's tank-irrigated rice production through their collected rental share. One English officer put it: "[B]y liberal and regular appropriation [for irrigation] of a small proportion of the revenue the produce and value of these districts may in the course of a few years be greatly increased and the country relieved from the present declining state" (TNSA, diary of the superintendent).

To the principal instrument of secure private property, over the next 150 years, the colonial rulers added other interventions to fight mismanagement, to enhance the efficiency of revenue administration, and to regulate water flows and resolve disputes in this unruly landscape of tanks and channels: among them, the law and the courts, new tax arrangements and administrative systems, cash-crop markets, engineering science, and coercive force. By the mid-nineteenth century, however, it was clear that colonial prescriptions were not working. Surveys indicated that a majority of tanks' embankments had been breached or were washed away so that they were "hardly distinguishable from the surrounding plains." Tank beds and channels were silted, while weirs and sluices were broken and vulnerable to further flood damage. Many tanks were irrigating less than half of their ayacut (the officially registered area of wet land), and large tracts of land were left uncultivated (SSRO, N. Minchin, "Report on the Tanks of Sholapuram, Sivaganga Zamindari," November 1889; see also Rajaram Row 1891, 498). ${ }^{6}$ Given the interlinked nature of the system, the condition of one tank significantly affected others. With heavy rainfall, breaches would occur along entire tank chains and river courses. By the 1930s, the zamindars' estate offices were being inundated with petitions for rent remission due to the resulting crop losses. ${ }^{7}$ In 1942 the Sivaganga estate engineer reckoned that only a quarter of the tanks in the estate were "in fair order [and] even they require large maintenance repairs" (SSRO, "Memorandum from Estate Engineer, to Estate Collector," Sivaganga, October 3, 1942), and the Madras Estates Land Act Committee (MELAC) reporting on the state of the zamindaris in the run-up to independence provided ample testimony to the disrepair of irrigation tanks which "instead of irrigating wet lands were [on breaching their embankments] devastating both wet and dry lands" (TNSA, MELAC, Oral Evidence, pt. 2, p. 114; pt. 4; see also TNSA, Court of Wards, December 12, 1936, no. 858). No new tanks had been constructed in Sivaganga, and only seven new works had been undertaken in Ramnad, despite the fact, MELAC complained, that "every small investment in an irrigation work either as a new work or as a renovation work brought in disproportionately larger rent to the Zamindar" (TNSA, MELAC, pt. 2, p. 231; GTN, 177:131-32). In fact, from the 1890s onward, zamindars sought repeatedly to divest themselves of responsibility for the estates' irrigation systems. The Ramnad zamindar, for instance, "issued a proclamation inviting people to make application for the lease of villages" (Rajaram Row 1891, 493).

${ }^{6}$ For different reasons, the situation was not much better in the adjacent government district of Madurai, where annual settlement reports between 1820 and 1850 show a reduction in the number of tanks by 32.75 percent, though there was a corresponding increase in the number of private wells (by 250 percent, from 1,127 to 2,827, between 1822 and 1840 [Bandopadhyay 1992, 45-49, 57, 151]). Such an increase in well irrigation was not a characteristic of the zamindaris for ecological reasons as much for politico-economic and tax-related reasons (see Mosse 2003).

${ }^{7}$ For example, a letter to the collector from the Sivaganga estate engineer (February 25, 1932) lists a total of 539 tanks and channels breached in the floods of 1931 . The bill for repair was estimated at 120,000 rupees (SSRO, office note, rent remission, seasonal, January 1932). 
With the deterioration of the irrigation system, the uncertainties of the monsoon were amplified, and yields fluctuated widely. Between 1912 and 1937, according to the Diwan of Sivaganga, yields had declined by half (TNSA, MELAC, 1937, pt. 3, p. 163); and in Ramnad the period of the British Permanent Settlement saw a quarter of tank-irrigated land turned into "uncultivable waste." Here, farmers without institutional credit and facing mounting debt to moneylenders had "alienated" an estimated 40 to 75 percent of agricultural land, swelling the numbers emigrating from famine-prone zamindaris to Ceylon and Burma. ${ }^{8}$ In short, under the Permanent Settlement, there was a massive failure to manage the inherent ecological uncertainties of tank irrigation. In 1947 these decentralized irrigation systems were in an almost total state of collapse.

Now the point is not so much that colonial prescriptions (of property, law, revenue, or engineering) were not working, but that as representations they concealed a more complex reality in which interventions taking the guise of bureaucratic rationality and resource management were experienced as arbitrary actions within an existing precolonial resources system. So, it is necessary to start with an understanding of the precolonial "rule of resources," not with the imposed rational schemes, and then to examine the effects of a range of interventions on this system.

\section{The Rule of Water: Warrior Power in the Precolonial Southern Plains}

To begin with, romantic images of a lost stable precolonial order must be set aside. When the British officers first encountered south Indian water-harvesting systems in the late eighteenth century, the condition that they described as "ruined" (by the corrupt native government) was probably not (as they believed) the recent collapse of an ancient irrigation tradition, but more the normal condition of tank systems in the Tamil plains.

These dense and intricate tank systems were produced and operated within a political-military system which guaranteed neither stability nor ecological adaptation and which constantly exposed tanks to the possibility of destruction. These systems were developed piecemeal by Maravar-caste warrior chiefs and kings, who, having long maintained autonomy from the Chola and Pandya dynastic centers (Ludden 1978; Stein 1980, 135-40), gained prominence with the militarization of the plains under the Vijayanagar empire from the fourteenth to sixteenth centuries (Dirks 1987). The most prominent Maravar overlord was the Cêtupati of Ramnad, whose power derived from the capacity to mobilize men through more-localized Maravar chiefs as well as from influence over important coastal trade links with foreign powers, principally the Portuguese and Dutch (Kadhirvel 1977). Until the seventeenth or eighteenth century, cultivation in Ramnad was extensive long-fallow slash and burn, combined with pastoralism and political and military service. Land was often held on military tenure: a foot soldier having entitlement to a plot yielding five "kalams" of rice (about $450 \mathrm{~kg}$ ); a musketeer, seven kalams; a captain, fifty kalams; and so forth (Rajaram Row 1891, 32). Militarization under the Vijayanagara opened up the plains as a source of troops and supplies but also resulted in expanding settlement by war-displaced populations

${ }^{8}$ The cooperatives set up in these estates were unable to meet the need for short-term loans. They failed miserably, and 100 to 120 out of 200 cooperatives established in Sivaganga were liquidated (TNSA, MELAC, Oral Evidence, pt. 3, p. 162). 
from the north. ${ }^{9}$ Tank irrigation allowed both for this settlement and for the intensification of agriculture. Moreover, it was also through building, repairing, and interlinking tanks that warrior chiefs-pälaiyakkärar or ampaläkkeârar-developed local political constituencies and extended their rights to grain-share revenues. Politicalmilitary domains, or nātus, were simultaneously created from hydrological interdependencies. Indeed, inscriptional evidence supports the notion that plains-area natus were often defined in relation to water sources. Natu size, distribution, boundaries, and subdivisions all had to do with irrigation sources (Stein 1980, 93-94), and the construction of dams or long channels (nāttar kāls) integrated otherwise highly localized tanks into larger systems as agriculture expanded between the sixteenth and eighteenth centuries (cf. Ludden 1979, 351).

In the militarized plains, Maravar chiefs could only build domains by offering some protection against a changing climate or fluctuating markets, theft, warfare, or the incursion of rival chiefs to whose domains cultivators could always move in response to oppression. ${ }^{10}$ They held district protection (têcam kāval) rights often granted by the sovereign overlord or organized more local village watcher (talam kāval) services and also acquired from cultivators the rights to grain-share payments, money, cattle, and other articles. ${ }^{11}$ The control of water and the repair of irrigation systems were part of this protection (for examples, see Mosse 2003, 65-66), just as the deprivation of water was also a method of warfare between rival warrior domains. Thus, in the wars of the 1780s and 1790s prior to the consolidation of British rule, the de facto rulers of Sivaganga (the Cervai-caste Marudu brothers) constructed a large dam across the Vaigai River to cut off the supply to the tank systems of downstream Ramnad (Nelson 1868/1989, 4:161). Armed conflict between local chiefs on two sides of a political divide broke out in the border area around Rajasingamanangalam and Paramagudi in the 1790s when a stream flowing into the Ramnad state was diverted (Kadhirvel 1977, 184).

As I have argued elsewhere, the relationship among warrior power, water, and domain building is recalled in the oral histories of today's inheritors of Maravar chiefly titles (Mosse 2003, 62-70). In these narratives, natu chiefs bring water and mobilize

${ }^{9}$ Maravar folk traditions tell of a period of expanding settlement in Ramnad/Sivaganga (much of it in the eighteenth century) by cultivator groups, notably Utaiyars, who were driven from the north (Utaiyarpalayam) into Ramnad by famine following the disruption caused by the invading Mysorean forces (of Hyder Ali) north of the Cauvery River. These accounts correspond with Jesuit histories, which, for example, record the land grants made to four Utaiyar chiefs by the Cetupati of Ramnad at the behest of his finance minister (Periya Annan Pillai Mandiri) on the grounds of their superior cultivation skills (JMMA, Fr. Leveil to Fr. Castets, January 17, 1929, Jesuit Annual Letters, vol. 8, p. 263; see also Mahé 1939, 14).

${ }^{10}$ The family histories of subcastes and their lineages in Ramnad today record movement away from the exploitation of Maravar kings. The pastoralist Konars of Alapuram Village, for example, tell of their flight from the Raja of Ramnad, who wanted one of their daughters for a concubine. They left their old village at night, concealing the girl in a large grain-storage vessel (Mosse 1986, 73). E. Valentine Daniel relates a similar story among Aru Nattu Vellalars (1984, 96).

${ }^{11}$ Significantly, while accepting the office of village watcher ("tallum cavel") as "an ancient, aboriginal system of Indian police," the British considered the supralocal district policing ("desh cavel") to be an intimidating and extractive protection racket imposed on villages, by which warrior chiefs gained great profit, interfering in the internal concerns of villagers and illegitimately extending their authority. The Maravars, one Company collector considered, were in fact themselves largely "responsible for the loss of all property stolen within their jurisdiction" (OIOC, report of Mr. Lushington, collector of Poligar Pescush, August 20, 1799, cited in the Fifth Report from the Select Committee on the Affairs of the East India Company, 1812). 
people for the protection of water rights vis-à-vis the claims of outsiders. They challenge upstream diversions and in doing so display warrior prowess and manage their relationships with the sovereign overlords from whom they receive legitimacy.

In a legendary dispute with the ampalār (headman) of Pulikanmai, the natu chief Yakappa Tevar refused water of the Nattar Kal (a "natu channel") to the people of this village because they had failed to help excavate it. The Pulikanmai ampalar, who had also been attacked by Yakappa, appealed to the Sivaganga raja. Yakappa was rebuked by the king for not referring the dispute to him and called to the palace at Sivaganga where the king gave him a challenge: "If you can pluck the coconut flower in the temple tank with the whip by your foot, you are a warrior" (Kōvil ürani tennaipālaiyai kālāl valacai kampunāl pālaiyai vilātțattinal, nī oru vīran). When Yakappa Tevar took the whip in his foot and did indeed pluck the coconut flower, the king was forced to concede that he was for sure a great warrior (viran $)$ with the power/right to arbitrate the flow of irrigation water in the Nattar Kal.

The point here is not only that warrior domains or natus were defined hydrologically and were protected militarily but also that they were linked upward to the overarching sovereign from whom local authority and rights to water derived. That is to say, in local historical narrative, the right to water was/is in the gift of kings. ${ }^{12}$ In the narrative above, chiefs such as Yakappa Tevar controlled land and water resources by virtue of authority that had devolved from the king and was expressed in the form of royal grant and title to the water of rivers or channels (see, for example, Mosse 2003, 63).

This upward linkage was most often expressed through systems of honors at regional temples whose present-day ritual provides a political memory of kingly authority and warrior power. ${ }^{13}$ Oral narratives reveal persisting links between publicirrigation work, warrior authority, and temple honors. For example, the ampalar of Cittatur Village acquired honor (mariyätai) at the major Kalaiyarkoil temple from the sovereign, including special invitation and the right to ride on the ceremonial palanquin, having cleared forest land, dug a tank and supply channel, constructed a temple, and initiated paddy cultivation, thus ensuring the increase in production and revenue. ${ }^{14}$ These Maravar heroes are viewed as converting public works through temples

${ }^{12}$ Nicholas Dirks (1987) shows that precolonial property more generally was part and parcel of social and political relationships expressed in the idiom of the gift from the king. The gift, he argues, was a mode of statecraft in the dry plains areas. In Ramnad both water and tax-free rights to tank fish and trees were gifted, for example, by Raja Kilavan Cetupati to the Maravar chief Yakappa Tevar.

${ }^{13}$ Temple "honors" usually take the form of presentations of cloth and betel and also sacred ash, sandal paste, split coconuts, cooked rice, or cloth at key moments in the main annual festivals. In the natu temple of Citanaru Natu near Sivaganga, for example, the natu chief and his pankealis (kinsmen) receive the first respect, or "silk-cloth respect" (parivatțam mariyātai), at the main pankuni month festival. Today, in addition to the Maravar ampalars, Chettiyar merchant and Acari carpenter caste groups sponsor the festival and receive honors. (We will later see how the loss of Maravar political power in the nineteenth century was reflected in the emergence of such new claimants to ritual honors.) The final and most important night's procession is sponsored by "the people of the palace" (aranmanaikarar), that is, the king or his representative - in this case, the Cervai-caste descendants of the Marudu brother-who receive the "first respect." In other words, the raja holds the final mantakapati, which is the right and distinction of sponsoring the procession of the image of the deity in its vehicle (vakanam) around the temple streets. A different group customarily sponsors each day of the nine-day festival.

${ }^{14}$ For other examples of temple honor acquired through repairing tanks or constructing link channels, see Mosse 2003, 66-68. 
into legitimate and titled authority linked to the sovereign. Some were among those big men who, as David Ludden suggests from a review of the Pandyan inscriptions (1985, 28-29), increased their influence, established regional links, and firmed up political relations with the sovereign-all symbolized in temple honors-by undertaking irrigation works outside their own localities. ${ }^{15}$

Temples also defined the roles and relationships of more-localized groups of villages interlinked by their dependence on shared water flows. Indeed, it is clear from present-day ritual practice as well as oral histories that the social organization around temple ritual (especially the festival processions of huge temple "cars") and that around tank irrigation reflect one another. Both express and contest rights and honors in the idiom of warrior power and shares in temple worship distributed as ranked "honors," of which the king holds the first. Both also reproduce relationships between dominant Maravars and dependent cultivators, especially Pallar-caste laborers who had/have a key role in operating village irrigation systems. Thus, the festival of the main temple of Citanaru Natu included honors for the (notional) twenty-two kutumpans, or Pallarcaste leaders of the natu. ${ }^{16}$ These low-caste "honors" clearly signaled inferior rank, both in the subordinate services to which they related (e.g., carrying the ceremonial umbrella for the ampalar) and in the manner in which they were distributed; that is to say, honors were not given to individual respected persons, but to an undifferentiated group, "the twenty-two kutumpans," to be divided among themselves (though Pallar informants identified important recipients of these honors by name). ${ }^{17}$

These local histories and rituals recall two things. Firstly, political relations were not independent of technical-ecological realities and physical processes: that water flows downhill, pools, and has to be allocated and shared and that labor must be mobilized to mitigate the effects of silt accumulation or corrosion. Water makes social connections and demands coordination. Secondly, irrigation systems had a political basis: villagers' rights in resources_-land and water-existed within a set of ranked political and military relations, and rights to water rested ultimately on ties with the ruling Maravar sovereign in Sivaganga or Ramnad — ties which might be based on military service or kinship, underlined by marriage relations or gifts of land, but publicly expressed in systems of temple honors. Today, the ceremonial affairs of temples are all that remain of the natus in Maravar country, domains which by the nineteenth century had been consolidated (and transformed) into revenueadministrative units. The tank systems became abstracted from political relations,

${ }^{15}$ The temple honors at regional temples today create a map of Maravar natu leadership in the area: the natu chiefs of Citanaru Natu, Manakalam Natu, Pakaneri Natu, and other warrior domains in the Sivaganga kingdom held festival honors in the major Kalaiyarkoil temple, while chiefs of the southern natus of Cettatel and Akkaramasi (in the Ramnad kingdom) held honors during the festivals of the major Nayanarkoil temple. Maravar chiefs not only held honors at major Hindu temples but also at Catholic churches during saints' festivals. The subject of honors, rights, and contests at Catholic shrines in this region is the focus of separate discussion elsewhere (see Mosse 1994, 1997a).

${ }^{16}$ Other ceremonially recognized hereditary roles and offices of the natu instituted by the sovereign include accountants (nāttu kanakku), police (kattai ampaḷār or kāval), and pastoralists (nātț mukkantar). There is no suggestion of any further institutionalized natu assembly in the region.

${ }^{17}$ Even if today temple ritual does not directly constitute political and economic relations, the privileged Maravar roles such as initiating the "car" procession and the more menial kutumpan role of erecting festival arches remain idioms of caste power and position in the microregion, and temple honors remain the focus of status competition and conflict. Moreover, these have a direct bearing on the social organization of tank irrigation (see Mosse 2003). 
(mis)represented in government offices in tables of statistics, physical structures, and topographical maps. But as "political technologies"- that is, ways of social ordering that influence how people work, relate, or produce over long periods - these irrigated landscapes and the ecologies and hydrologically mediated relations that they produce long outlive the particular political alliances that created them (Winner 1999).

\section{Gifting Water}

I began with the question of localized control over water and now turn to the overarching political power at the level of the kingdom and to the person of the Maravar king. It immediately becomes clear that this power itself was not founded on the centralization of control over land and water resources, but rather the reverse. The definitive acts of kingship were not the establishment of systems of taxation or engineering projects, but the dispersal of state resources through gifting (Dirks 1987; Price 1996). Rights over land or to revenue and rights over water sources and water flows were gifted to royal kinsmen and warrior chiefs, royal retainers, village officers, artisans, and especially religious institutions - temples, pilgrim rest houses (cattirams), monasteries, mosques, and communities of Brahmans. ${ }^{18}$

By the nineteenth century, property and revenue rights in 64 percent of Sivaganga's 2,058 villages (and about half of Ramnad's), together with tanks and certain associated water rights, were recorded as gifted, 70 percent of these grants having been made before 1800. At least 739 irrigation tanks in 389 villages had been endowed to 106 named temples (SSRO, "The list of settled inam villages in the Sivaganga Zamindari prepared from the Dharmasanam registers under the supervision of the Inam Deputy Collector in 1906," Ramnad, 1911). Major temples (or pilgrim rest houses) were granted 60 or more tanks, while the produce of smaller tanks supported village temple priests, goddess festivals, or tombs (such grants often being managed by persons conducting the worship). Through this gifting, the rajas produced complex mosaics of subordinate land-holding domains headed by royal kinsmen, natu chiefs, Brahmans, and managers of temples and monasteries that were integrated through the transactions of the regional temples and their ritual systems.

These gifts transferred the king's "upper share" (mèlvāram) of the produce of entire villages to the grant holder. Other more local forms of entitlement related to individual plots of land within villages. Traces of these latter land grants (māniyams) are found in the field names in today's tank commands, which, together with the list of village shareholders recorded by early Company officers, give a picture of the major stakeholders in Ramnad and Sivaganga society in pre-British times: the temples, Maravar village heads, Pallar-caste servants, pastoralists, and a range of other service tenures ranging from water turners to cobblers and temple dancers. ${ }^{19}$

In consequence of the royal grants, in a very large part of the region the state had given over its right to a fiscal share of the produce from land and water resources. From the remaining land there was little by way of extractive revenue. Grain from

${ }^{18}$ In Ramnad and Sivaganga, royal gifting was characterized by the granting of entire villages under charitable and other forms of patronage. The beneficiaries of granted (inamm) villages paid only a small fixed tax ("poruppu") per unit of wet land (nañcai) to the raja.

${ }^{19}$ Devadasis - female dancers - were consorts of the "ruling" deities at the level of village, region, or kingdom. As symbols of royal sovereignty and auspiciousness, they were patronized by Maravar headmen and chiefs as well as kings in precolonial Ramnad and Sivaganga (Price 1996, 69). 
cultivated fields was apportioned into shares, including the overlord's upper share and the cultivator's "lower share" (killväram), as well as shares for a range of village officers, artisans, and servants. Between 10 and 40 percent of harvested grain was redistributed in the form of these village public (potu) shares. More generally, the way that this grain-share revenue system (varam) worked was redistributive rather than extractive in that, while bringing the interests of the state deep into processes of production in individual villages (e.g., through grain assessments and the supervision of harvests), the system of shares and land grants fed a large proportion of the surplus notionally extracted by the state back into local production (Washbrook 1988, 63-64). A significant part of these redistributed resources went toward the physical (and ritual) maintenance of tank irrigation through the support of artisans, water turners, ritual specialists, and headmen through land grants and grain shares (for details, see Mosse 2003).

Now the logic of the gift was partly political and partly economic. Politically, the dispersal of resources was a means to renew political alliances and military support to resist external threats (or internal challenges), not least from the British, whose tribute demands were strongly resisted in the 1780 s to $1790 s .{ }^{20}$ More important for my purposes is the gift's economic logic. In the southern plains, this kind of religious gifting coincided with the period of agricultural expansion from the fourteenth century. The question is why productive investment took the form of temple endowments. Furthermore, why did investors channel investments through deities rather than directly into irrigation? My argument (following Carol Breckenridge [1985] and Burton Stein [1960]) is that, in endowing temples (and Brahmans, monasteries, pilgrim houses, and so on), rulers had evolved a strategy of statecraft specifically adapted to the peculiar risks and uncertainties of the tank-irrigated southern plains (Mosse 2003, 70-75). Here, in the first place, significantly increased ecological risk was associated with the expansion of irrigated rice cultivation into a dry region through rain-fed tanks subject to the devastating effects of drought and floods; in the second place, increased social uncertainty resulted from the settlement of a socially diverse and mobile population displaced by conflict and war.

Firstly, then, in ecological terms, tank-irrigated agriculture involved uncertainties that differed from both riverine paddy cultivation and long-fallow dry farming. It required investment and involved risks which were beyond the capacity of individual cultivators or even individual villages but which the state (Maravar, Nayak, or Vijayanagar) constantly sought to devolve to lesser domain holders-that is, temples, monastic institutions, military chiefs, Brahman communities, chattirams, and merchant "revenue farmers," among others. ${ }^{21}$ The uncertainties of tank irrigation demanded an authority in agriculture, not as Karl Marx or Karl Wittfogel imagined the authority of the overarching state, but a decentralized authority produced through the politics of the gift and especially the endowment of temples (see Breckenridge 1985, 61). Temples (and Brahman communities) were endowed with villages to develop and

${ }^{20}$ Military correspondences of the time detail the difficulty that British officers had in extracting tribute from independent Maravar rulers in Ramnad and Sivaganga, or the palaiyakkarars and de facto ruling kaval (police, security) chiefs in Tirunelveli on behalf of the Nawab of Arcot (Kadhirvel 1977).

${ }^{21}$ Velcheru Narayana Rao, David Shulman, and Sanjay Subrahmanyam draw a similar conclusion for the Nayaka states, emphasizing the growing importance of enterprise and the "privatization" of revenue collection $(1992,104)$. 
maintain tank systems (see Dikshit, Kuppuswamy, and Mohan 1993, 66). ${ }^{22}$ Such grants also went along with land grants for tank-maintenance services-in Karnataka, one-tenth of the ayacut (dasavanda) or some other specified share of the land or harvest (Dikshit, Kuppuswamy, and Mohan 1993, 74).

Secondly, in relation to social uncertainty, these endowed temples also provided redistributive mechanisms through which the diverse and migrant populations displaced by warfare between the sixteenth and eighteenth centuries were incorporated into the marginal tank-irrigated areas through "charters of entitlement" (Breckenridge $1985,58-59)$ such as grain shares symbolized in temple honors.

So, tank irrigation in Ramnad and Sivaganga was not an autonomous village affair (which is where neotraditionalist historians and environmentalists are wrong), ${ }^{23}$ but was, between the sixteenth and eighteenth centuries, part of the political and military organization of the southern plains. But in suggesting how a decentralized political system was organized to cope with ecological uncertainty, I am not implying that it guaranteed stable or sustainable cultivation-far from it. As noted, the political incentives to invest in new irrigation works were probably always greater than those to maintain them (as remains the case in present-day state investments in irrigation). Many tanks would have attracted the patronage of warrior chiefs and local magnates who lacked resources for the expensive task of repairing them once they were breached (Ludden 1979, 352; 1985, 144-47). Anyway, such investment probably sustained rather small or short-lived areas of paddy cultivation serving to advertise the power, protection, and ordered society of warrior chiefdoms in ways that were symbolic as much as economic. Sporadic works interspersed with periods of neglect or damage meant that at any historical moment, a significant proportion of tanks would have been in disrepair or abandoned-as the late eighteenth-century surveys of the early Company officers indeed showed - though this may have been exacerbated by the escalation of military conflict in the immediate precolonial period. This was also a period of extensive tank works - the construction, repair, and excavation of link channels - as well as the patronage of temples and the granting of villages to allies. To extend Nicholas Dirks's point, warfare and tank building were two elements of the same mode of statecraft.

${ }^{22}$ Hydraulic engineers, masons, and others more directly involved in tank building were also beneficiaries of royal land grants in Karnataka. In the core riverine regions, Brahman communities had long been objects of patronage by politically dominant groups and had acted as "mediating agencies for temple investment" as part of a powerful and dominating alliance between Brahmans and land-controlling Vellalar castes (Ludden 1985, 40).

${ }^{23}$ Dikshit, Kuppuswamy, and Mohan, for example, maintain that "[b]efore the introduction of British administration in our country, in the nineteenth century, the construction and management of our tank system was in the domain of the local village community.... $[\mathrm{N}$ ]ormally the repairs and maintenance of tanks were the responsibility of the local assembly" (1993, 43, 45-46, 225). Inscriptional evidence certainly demonstrates the existence of ancient village assemblies and tank committees, particularly for Brahman villages. The point, however, is that, politically speaking, the recorded self-government which brabmadêya villages (those granted to Brahmans) enjoyed was itself a privilege granted by regional chiefs or rulers. It stood in contrast to ordinary peasant settlements (Stein 1985, 62; 1980, 419). As Stein notes, the brahmadeya settlements "were ultimately under the political control of the nattar [chiefs of the natu or microregion] and dependent, as all of the locality were, upon the latter's management of local production, upon their resources and above all their protection" (1980, 419; see also Subbarayalu 1973). For an alternative view of the role of brahmadeya villages (as mechanisms to assert Chola state control), see Karashima 1984. The literature on natu domains is well reviewed by Mizushima 1986. 


\section{Zamindari Rule}

The substitution of plunder and largess by what came to be represented as bureaucratic rule and revenue under Pax Britannica (see Dirks 1987, 48) had important consequences for the functioning of these decentralized irrigation systems. Indeed, it was the colonial rupture of an earlier form of rule, rather than the state erosion of traditions of the little community, which contributed to change in the nineteenth century. The damaging effects of colonial rule on decentralized tank systems, however, were neither immediate nor direct.

British colonial rule did not produce a radical break with indigenous political life and modes of statecraft (see Price 1996, 1979b; Baker 1984; Dirks 1987). The secure property rights brought by the Permanent Settlement did not result in efficient resource management within new zamindar domains because "property" did not work as an abstract principle or as a "generalized regime of government" (Mitchell 2002, 58) separate from the political relations on which actual claims to resources depended. Rights over land and water emerged from a series of particularistic local actions and circumstances. In fact, the former kings resolutely refused to define for themselves an entrepreneurial role as landowners or to ensure the rigorous administrative and revenue systems that colonial expectations demanded. From 1800 until the abolition of their estates after 1947, the zamindars of Ramnad and Sivaganga refused to abandon their political rule as kings and rulers for an economic role as estate managers.

These former kings confounded British expectations about profiting from efficient management and the expansion of paddy cultivation. Instead, estate land and water were again treated as resources to "rule" (cf. Neale 1969) - to disperse to lesser domains through patronage and redistribution in the pursuit of political strategies and royal honor. The gifting of land and water resources (villages and tanks) remained a central political strategy for rajas, ranis, and other contenders to the royal seat, each seeking to legitimize royal status through patronage and largess. During her fouryear "reign," the first zamindar in Ramnad (Mangalesvari Nacciyar) granted numerous villages in perpetuity, including a group of "ninety-six dharmasanams" (endowments to Brahmans, temples, and chattirams) (Rajaram Row 1891, 261). The royal zamindars, like their estate managers and royal kin, sought to secure power not through ownership of property, efficient revenue collection, or irrigation maintenance, but through the dispersal of resources and gifting (Price 1979a, 228; Rajaram Row 1891, 480-81). Indeed, Pamela Price (1979a) draws a direct parallel between the extravagant largess of certain estate managers of Sivaganga and the practices of their precolonial counterparts - in particular, the Cervai-caste Marudu brothers, palace servants who became de facto rulers of the Sivaganga kingdom in the 1790s and legitimized their assumed royal status through the prodigious gifting of resources to temples, Catholic churches, and other religious institutions.

Each Maravar zamindar was reluctant to protect proprietary estate land and water through entrepreneurial investment (which might anyway only enrich his or her competitors), but instead sought to preserve his (or her) position as a generous lord-to be, as the donative inscriptions proclaimed him (or her) to be, "a great and wealthy Lord of the world ... munificent in gifts of food, alms and in building cattirams ... guardian of honours, protector of pilgrims. ${ }^{24}$

${ }^{24}$ This inscription was from one of many copper plates in which the king's gift is prefaced by a laudatory text identifying the king particularly as warrior and donor (carva maniyam in favor of the church at Sarugani 1801, from Vallava Periya Utaiya Tevar, Raja of Sivaganga, taken from a translation of the original copper plate, Jesuit Madurai Mission Archives). 
In some taluks (subdistricts) such as Kamuthi in Ramnad, as many as 34 percent of the village grants were established after the creation of the Permanent Settlement. A survey of 1,283 tanks undertaken in the 1930s showed the outcome of extensive gifting in Sivaganga. The produce of over a third of all the wetlands had been granted to temples, cattirams, or Brahman communities, especially in the taluks of Tiruppuvanam (where 38 percent of the wet land was managed for temples), Kandavevi (36 percent), and Tirrupattur (32 percent). In certain revenue divisions (e.g., Madapuram and Pirmanur of Tiruppuvanam Taluk), the entire wet land were under dêvastanam (temple) control.

These strategies of rule, however, were significantly changed by the new arrangements of British India. Disarmed Maravar rajas no longer gifted to warriors whom they would lead into battle, but instead to those who would support them (politically and financially) in ultimately ruinous litigation over the succession of royal titles. The economic consequences of legal "warfare" were very different from those of military campaigns. The Maharaja of Bobbili noted, "in battles, the conqueror . . . annexes the enemy's country, or secures certain commercial privileges. But in litigation, except in a very few instances, the winner gets nothing" (Price 1996, 79). Price estimates that by 1868 one of the zamindar's estate managers had involved the Ramnad estate in debt of at least 1.45 million rupees (1979b, 231-32).

The nature of gifting had also changed. In the nineteenth century, temples no longer exerted the same control over agriculture or provided the possibilities for independent investment that they had earlier. Rather than endowing temples or pilgrim rest houses through royal grants, the zamindars made favorable leases, or "cowles" (kavuls), which transferred the right to the melvaram to royal family members; ${ }^{25}$ political allies; and especially (in return for cash advances) Chettiyar bankers, who were the principal financiers of litigation over royal succession and honor. ${ }^{26}$ At the end of the nineteenth century, Nattukottai Chettiyars controlled massive capital; had become the chief merchant banking caste of the south; and "monopolized important components of the credit, banking and agrarian systems" in Burma, Ceylon, Malaya, and the Madras Presidency (Rudner 1989, 423-24; 1994). Already trading zamindari melvaram grain and mortgaging or leasing villages as security against loans, Nattukottai Chettiyars had (unintentionally) become zamindar overlords of villages, acquiring possession of large parts of the Ramnad and Sivaganga estates on permanent lease in place of debts (A. L. A. R. Chettiyar family, interview, December 10, 1993; see also Rajaram Row 1891, 484; Price 1996, 103-4). By 1895, A. L. A. R. Ramaswami Chettiyar, the chief creditor to the zamindar of Ramnad, was the major recipient

\footnotetext{
${ }^{25}$ Zamindars created perpetual leases to benefit and maintain family members partly as a means to exempt villages from attachment by creditors or their inclusion in leases for the discharge of debts. When the Sivaganga estate was handed over to three European lessors to cover debts, nearly sixty villages had to be excluded from the agreement, because so granted, including six leased permanently in 1887 in the name of the raja's first wife (SSRO, indenture, May 23, 1887; "Brief History of the Inter-pleader suit O.S.No.55 of 1906 on file of the Subordinate Judge's Court," Ramnad).

${ }^{26}$ In conversation, these leases are today referred to as kuttakai, a fixed tenancy. Leases were of different kinds - most were fixed-term leases for periods of between five and forty years, but a number of villages were permanently leased or were assigned as gifts. Cowles could produce profits (over the fixed payment to the zamindar) from 25 to more than 659 percent, and the more profitable cowles feature strongly in those given away as forms of largess by estate managers (Price 1979a, 227). As court records indicate, it was not always easy to recover leased villages (see, for example, TNSA, "Suit for recovery of Kiranur village," Court of Wards, August 15, 1906, no. 2081M).
} 
of some 600 village leases and at one time possessed over 800 villages, including whole taluks and several revenue divisions (Price 1996, 184). In 1889 the banker and his partners took a lease on the whole Ramnad zamindari (Price 1996, 187). Chettiyars also took over devastanam and chattiram villages that had been granted for the maintenance of temples and pilgrim houses, respectively, against royal debts. According to a report of 1901, in Sivaganga 183 out of 559 devastanam villages and 19 out of 83 Chattiram villages were leased as cowles (TNSA, 1901 administrative report on Sivaganga Devastanam and Chattiram, Fasli 1309, Court of Wards, September 20, 1901, no. 55P). The former were usually taken on long (fifty-year) leases specifically to rebuild and manage major temples such as the one at Kalaiyarkoil (Chettiyar family, interview, December 10, 1993).

Like royal kin to whom separate domains had been granted, ${ }^{27}$ Chettiyars set up their own revenue-collection establishment, granted land titles, appointed local Maravar ampalars, organized village services, had the responsibility for irrigation repairs and the authority to mediate disputes, and paid tribute to the rajas. They made themselves "royal" personages in every respect. They became patrons paying for festival processions, inaugurating new rites (kaț̣alai), and receiving first honors along with the raja and regional chiefs. They received first honors at the village temples on their estates. And when, on May 8, 1919, two Chettiyar children turned up for their first day at the Roman Catholic school at Sarugani, they were accompanied "with drums and pipes"; betel, veștis (dhotis), and money were presented to the teachers (JMMA, Sarugani Parish Records, Sarugani Parish diary entry, May 8, 1919).

Not surprisingly, the British government viewed the donative strategies of the zamindars as a contravention of the principle of property, constituting "mismanagement" of the estate and a "frittering away" of all of its assets, "the estate becoming heavily encumbered and mortgaged and absolutely impoverished, with many questionable titles being created" (Government of Tamil Nadu 1977, 457). Indeed, the colonial administration did its best to contest endowments and leases in the courts. In 1873 the Ramnad collector issued a notice-subsequently contested-to all cowledars informing them that their leases were to be canceled, and the villages resumed to the zamindar (Dirks 1986, 327). But even though some 3,848 suits were initiated and 104 "alienated" villages in Ramnad were recovered by the government under the management of the Court of Wards between 1873 and 1882, 323 of the estate's 2,168 villages remained "alienated" in 1886, as zamindars continued to gift, grant, or lease their villages (Dirks 1986, 328-29; Rajaram Row 1891, 475-97).

The British took a similarly dim view of the zamindari "share" revenue establishment, which involved a parallel persistence of "redistributive" practices geared toward the dispersal of power and resources rather than the efficient landlord rent collection taking place under the guise of a complex of rules, harvest estimates, permissions (to cut, stack, transport), measurements, surveillance, and payoffs. The interests of estate officers, village elites, and traders were brought together through a revenue system that combined with the village-level hereditary grain-share rights to reproduce the local social order while ensuring that only a small percentage of the notional royal "upper share" of the grain ever reached the estate granaries. Once there, one contemporary critic noted:

At last, come upon the scene, a set of unscrupulous fraudulent tradesmen, or relatives or friends of those in authority, or mere speculators professing to give security which

${ }^{27}$ Muthu Virayi Nachiyar, a royal widow and contender for the Ramnad throne, held the twenty-three villages of Pidaranendel Division on permanent lease. 
is really worthless. These men bid higher prices and take up the grain in lots they require. They remove the grain, but make no payment down, but enter into promises to pay the value in eight instalments and profess to give due security for the fulfilment of the promise. It not infrequently happens that the purchaser decamps, and his surety is found to have followed suit, or found to be hollow. The money due on the sales to the relatives and friends of the Officers outstands the longest. If, to avoid these troubles, the grain is taken direct to the nearest market, to be there sold outright for cash, few could be induced to pay the market price, the Circar [state] grain being notoriously bad, and unscrupulously adulterated.

(SSRO, A. Seshiah Sastri, Pudukottai State administrative report, 1879-80)

Above all, the grain-share revenue system was viewed as a major obstacle to land improvement and a disincentive to progressive farming, especially of rice. "It pays no man of enterprise or capital to take to farming," commented one governmentappointed estate manager (Rajaram Row 1891, 464).

The colonial administration tried to eliminate the redistributive elements of the system, firstly taking control over village headmen and accountants away from the zamindars (paying a salary instead of shares in the rice harvest) and secondly (most crucially) in Sivaganga (under the Court of Wards) replacing the grain-share revenue system altogether with fixed taxes in cash, with the expectation that this would lead to reinvestment in paddy cultivation and irrigation. But again, the move was both misjudged and ineffective. Tax demand and arrears escalated when grain prices fell in the Depression years and farmers could not pay rents fixed at high 1920s levels. There were so many rent claims to contest that in 1929 the law section of the Sivaganga estate was engaged in 14,253 suits (and14,418 suits in 1930), prompting the appointment of a paid law agent to keep costs down. The majority of suits ( 99.5 percent in 1930-31) were decided in favor of the estate, and increasingly coercive measures were taken to recover dues, including the forced seizure of movable property and standing crops (instantiating property as concrete force rather than abstract principle). This had little practical effect. Farmers and junior estate officers had begun actively and effectively to subvert the new demands, as reflected in the spate of reports in the early 1930s, legal suits, and convictions relating to embezzlement by revenue staff and village headmen (for Sivaganga, see TNSA, Court of Wards, October 31, 1931, 482 M; Court of Wards, August 12, 1931, no. 349; for Ramnad, see TNSA, 1938 proceedings in Court of Wards Index, including eleven separate cases). Then, under oppandams (lit., "agreements," contracts), villagers put up organized resistance. When the taluk inspector and peons (police) from the town of Manamadurai went to distrain some bags of ragi (millet) and paddy in Rajagambiram Village, they were attacked by ryots (tenants), "who forcibly took away their bulls and the bandy" (TNSA, administrative report, Fasli 1341, Court of Wards, December 15, 1932, no.31P; administrative report, Fasli 1340, Court of Wards, December 9, 1931, no. 31P). Significantly, organized resistance to the estate focused precisely on those warrior-caste (Maravar or Kallar) "shareholders" of the old regime. Initially these "shareholders" organized to petition: Kallars, for example, under the Ramnad District Kallar Mahajana Sangam, met at Paganeri (an old natu center) and passed resolutions, including a demand for a 50 percent remission in cash rent. Then, increasingly violent defiance and resistance was recorded in a rising number of arrests and many thousands of criminal cases between 1928 and 1932 (Mosse 2003, 130n65). In 1931 the ryots of Kalapoor and Singapuneri villages refused to pay rents. An official report complained that "[w]hen one of them was arrested on a warrant an isolated agitant garlanded and took him in procession, obviously with the intention of appealing to the imaginations 
of other ryots and encouraging them to withhold rents from the estate" (TNSA, administrative report, Fasli 1340). Officials attempting to collect rent were excluded from villages, attacked, and even shot dead (Mosse 2003, 203); severe sanctions were imposed on those who broke ranks and paid their overdue rent, extracting fines and in extreme cases even setting fire to their houses (Mosse 2003, 118).

Portrayals of mismanagement, illegal alienation, inefficiency, corruption, agricultural disincentive, "criminal intimidation and force," and estate-impoverished ryots "destitute of the ordinary comforts of life" and reduced to "emigration to Colombu, Penang and Colonies" (Rajaram Row 1891, 75) accompanied a new colonial representation of government, which involved the rule of property; the separation of peasants from the state, private from public, gift from contract, secular from religious; and an emphasis on bureaucracy, revenue, law, enterprise, and profit. This was a representation that simplified and concealed the actual social processes of zamindari rule. The universal principle of legal property right (in the form of the Permanent Settlement) clearly did not have the effect of rationalizing the management of productive resources, but rather perpetuated their dispersal. Zamindar-rajas continued to treat land, irrigation systems, and their produce as political assets to rule — to gift, disburse, and redistribute to cement political alliances, secure credit, reward services, or acquire honor and religious merit-rather than as resources to manage. Citing J. C. Heesterman, Price argues that they continued to display kingly authority understood as the "power of allocation," involving a "diffusion of power and a scattering of resources" (1979a, 209, 211). Zamindari strategies resolutely refused to produce a world that could be divided into categories such as state and peasantry, private and public, religious and commercial. They transgressed principles of tax and property. They endorsed temples and Brahmans as domain holders while creating openings for new types of landholders, especially Chettiyar bankers (Price 1996, 102). This further fragmentated the authority of the state into a multitude of lesser land-holding domains created through royal gift and privileged tenure and superimposed upon the impartible zamindari estates, which the British assumed would consolidate rural power and resource management in key districts around gentlemen landlords. As in precolonial times, the gift was an economic as well as a political strategy geared toward the uncertainties of tank-fed agriculture and the unreliability of estate fiscal resources. The various local overlords not only acquired the rights to the ruler's upper share but also inherited the royal obligation to invest in the maintenance and improvement of irrigation works, temples, and other "public goods." This was recognized oth in their receipt of a kulaveț̣u (tank-cutting) grain share and symbolically in honors at local temples. ${ }^{28}$

\section{Kingly Rule of Resources under the British Raj}

Despite continuities with kingly modes of governance, under British rule the plains water-resources systems were profoundly changed. For one thing, although

${ }^{28}$ The situation was slightly more complicated where tank resources were shared between estate and granted (inam) villages. Before 1850 inamdars or cowledars drawing water from samastānam (estate) tanks were obligated to pass this grain share on to the estate; having received kulavettu payments, the zamindar was bound to maintain the tank or to compensate the cowledar if he undertook the repair (see, for example, SSRO, "Sivaganga Rane Cowle dated 27 October 1874," Court of Wards, March 27, 1900, no. 426). After 1852 there was no longer a demand for kulavettu, but for a proportion of the cost of works undertaken. 
nineeenth-century "zamindari rule" perpetuated the diffusion of power and property, it conspicuously failed to devolve the corresponding obligations to invest in the maintenance of crucial productive irrigation resources that had characterized an earlier regime. ${ }^{29}$ The vivid reports on the parlous state of tanks in the zamindaris at the end of the nineteenth century are ample testimony of the failure to redirect resources into irrigation. This crisis in ecology and agriculture was not (as is commonly viewed) a consequence of the erosion of community management by the bureaucratic actions of a centralizing state, but rather evidence that the strategies of kingly rule were themselves altered by the conditions of British India.

First, in British India, the logic of the "gift" had itself changed or reversed. From the zamindars' point of view, royal patronage was not (as it had been) a means to create autonomous nodes of investment in irrigation, but rather a device to generate cash flows to the zamindars' offices-in the form of banker's credit or commandeered temple funds-without the obligation to invest in public goods (see Price 1996). Under the old regime, local authority and rights to a fiscal share of the produce implied and required investment in tank irrigation, but this political and economic logic no longer applied. The crux of the problem was that, while irrigation systems remained political institutions incorporated into the decentralizing strategies of rule, after 1800 zamindars had little real political power to devolve-theirs were, so to speak, "hollow crowns" (Dirks 1987). While zamindars continued to disperse resources and to create subordinate landed domains, they lacked the power to integrate these politically. These domains were no longer integrated through major regional temples such as Kalaiyarkoil (now leased to Chettiyars). At the same time, domain holders began to refuse the rajas and ranis one particular grain share called makamai normally given for support of Sanskritic rites at the zamindar's titular temple, among other things, which symbolized the integration of subordinate domain holders into the samastanam (estate). ${ }^{30}$ Clearly, the link between irrigation investment and its political rewards was severed.

Second, investment incentives were weakened further by insecurity of tenure within the many new landed domains. By challenging cowle leases in court, the British government generated pervasive insecurity around leaseholdings, certainly in comparison to religious endowments. Religious endowments were in fact also questioned by the government; by the late nineteenth century, however, so many of the attempts to cancel religious grants-especially dharmasanam grants in the hands of Brahmans- had failed in the courts that the government's Court of Wards (acting for the zamindars) had given up contesting them (Rajaram Row 1891, 477). The relative security or insecurity of tenure translated visibly into the condition of tanks, so that the author of an 1889 survey in Sivaganga could note that tanks held on cowle lease were in particularly poor state but that "wherever we saw a tank in good order, we were informed it was a dharmasanum grant" (SSRO, N. Minchin, "Report on the Tanks of Sholapuram, Sivaganga Zamindari"). The fragmentation of landed domains across a hydrologically interlinked irrigation system (as a result of new multiple forms of "gifting") created further disincentives to invest. Many villages were under joint or multiple tenure. "Shares" in Piramanur Village in the Sivaganga zamindari, for

${ }^{29}$ In the nineteenth and twentieth centuries, the failure to maintain tank-irrigation systems also became a reason for zamindars to devolve their control over them to others.

${ }^{30}$ In the 1850 s, for example, Muthu Virayi Nachiyar, royal kin and holder of Pidaranendel Division, refused to pay the makamai fees as an expression of her contempt for the "ruling" Parvata Vardhani's authority (Rajaram Row 1891, 483; Price 1979a, 223-24; 1996, 88-90). 
example, were divided among the devastanam estate of the Meenakshi temple in Madurai (endowed for ritual services), dharmasanam (Brahman) cosharers, and a private shareholder of the Viswanathasamy temple devastanam in Madurai who had leased his shares to one Alagarswamy Naikar (SSRO, office note from estate engineer to estate collector: subject-irrigation contribution-Piramanur tank and channel repairs-collection, April 10, 1932).

Court cases that I reviewed in the Sivaganga Record Office clearly show that zamindars could not enforce irrigation-maintenance obligations on subordinate domain holders-but neither could the colonial government enforce such obligations on zamindars. ${ }^{31}$ Indeed, zamindar estate expenditure on irrigation works was erratic, usually ad hoc and responsive to petitioning by village leaders, and often amounted to no more than 1 percent of the revenue demand (SSRO, Court of Wards, February 26, 1901, no. 70M; Court of Wards, February 28, 1913, no. 292 Mis). ${ }^{32}$ An effervescence of litigation over tank-maintenance obligations from the late nineteenth century is testimony to the failure of authority — or at least a failure to constitute local authority through public works. Not only did law and the courts fail to substitute for warrior authority, but also the attempts to legally codify and enforce rights and duties in relation to water only served to weaken the link between lordship and investment (see Mosse 2003, 104-9). In any case, a shortage of labor and transport (owing to drought and emigration) had increased the costs of irrigation works, and itinerant Ottar-caste tank diggers, on whom works often depended, were not reliably available or commandable. ${ }^{33}$ Moreover, quarried stone was only available from the coast and had to be transported at considerable cost (TNSA, diary of the superintendent; see also Price 1979b).

When it came to the regulation of water flows, I found an even greater volume of litigation over rights. Anglo-Indian law was founded on precedent and principles of universal applicability and formalized ideas of riparian rights or the right of prior appropriation. But as lengthy and unresolved suits reveal, it struggled hopelessly to lock a highly interconnected and changing hydrology into an enduring set of generalized rules, codes, and rights. ${ }^{34}$ In fact, as parties in dispute vied to construct au-

${ }^{31}$ For example, in 1908 a Madras High Court decision confirmed the right of the holder of an old jivitham (personal services) inam village (Vellikurachi, which was gifted by Tirumal Nayak) to refuse to contribute to the cost of repairs on a large tank supplying this and a number of estate villages (judgment on appeal no. 65 of 1908, High Court Madras). I am grateful to Pamela Price for sending me a copy of this judgment. Equally, there were several cases against the samastanam concerning claims by inamdars or cowledars for the reimbursement for work on tanks and channels benefiting the estate (see, for example, TNSA, Court of Wards, March 27, 1900, no. 426; December 9, 1901, no. 1936; September 5, 1904, no. 2428M; September 19, 1904, no. N2577M; November 28, 1906, no. 2855M; July 4, 1906, no. $1131 \mathrm{M})$.

${ }^{32}$ Villages differed widely in their capacity to mobilize estate resources for tank repairs. Villagers well connected to the palace recall repairs every five years, while less-well-linked villagers hardly saw any repairs.

${ }^{33}$ The capacity of contractors to negotiate lower wages with these itinerant specialists was limited. The tension between contractors and Ottar workers, their mobility and "otherness" to local society, is a common theme reflected in the story narrated by a Paraiyar woman. When the Chettiyar contractor of Pulikanmai delayed payment to a group of Ottar laborers, an Ottar woman placed a basket in the tank and covered it, cursing the place: "However much it rains, this tank should not fill" (evvalavu malai peytālum inta kammāy perukkūțātu). Today villagers still complain of the poor water supply in this tank.

${ }^{34}$ In Ramnad and Sivaganga, rights over water flows in the tank system involved rules which were rarely codified or written down. Court cases have only occasionally been able to 
thoritative landscapes and antecedent water flows to their advantage, the courts produced a "new traditional" discourse of natural water flow, customary (mamul) use, and entitlement by royal grant (Mosse 2003, 105-9), which only further destabilized water rights.

Along with new law, the British administration by the 1930s had also introduced masonry and cement as a means both to fix water disputes and to impose a new engineering notion of efficiency. But invariably, solutions engineered in cement brought new controversy and resistance. In 1943, in the village of Sullangudi, for example, villagers objected to the estate's "improvement" of irrigation through the construction of a cement dividing dam across the Nariyar stream (replacing impermanent brushwood korumpus) on the grounds that it diminished their tank supply. But, the Sivaganga District Magistrate ruled that "the estate [at this point administered by the government] has got the sole right in the matter of regulation and distribution of water for irrigation of estate ryot land by way of improving the irrigation sources and construction of permanent structures for regulation and proper distribution of water without allowing to go to waste. . . Ryots cannot interfere with the construction of any masonry works in the said Nariyar course for the proper distribution of the drainage water for irrigation of lower down tanks" (SSRO, report submitted to the estate engineer from overseer, Tirukoshtiuyur Taluk, re. suit notice from Sullagudi ryots, December 13, 1943; emphasis added). ${ }^{35}$ These interventions further eroded the old "rule of water," but they (and the conflicts that they provoked) also draw attention to the "negotiable" technology through which this rule had formerly operated, that is, impermanent brushwood structures deliberately washed away in the early monsoon to fill lower-down tanks. ${ }^{36}$

Decentralized investment in (and mediation of) irrigation was, then, undermined by a failure of local authority brought about by the progressive but unsystematic inroads of British rule. In a variety of political, administrative, and technical ways, the British had removed power from the zamindars, while their own interventionsover property rights or through their courts or masonry-served only to increase the insecurity of tenure and add to the instability of the system. The problem was that zamindari society still operated as if state power was dispersible (as it previously had been), while in reality under the colonial state it was not. The loss of political power at higher political levels reverberated down the system such that, by the end of the nineteenth century, there was in Ramnad and Sivaganga a new and widespread failure to constitute local authority through public works at every level. Given that alternative downward accountabilities (i.e., democratic pressures) had yet to evolve, irri-

cite evidence of royal grant, though the belief in the existence of pattaiyams, or records of royal grant and privilege, relating to tank water supply is today quite common. Interestingly, in some big tanks in Vellore, Arcot District, customary rights and rules of intervillage allocation (māmul nammar) were systematically recorded by the British in 1815 (drawing on an earlier unwritten tradition) and became authoritative statements in negotiating diversion structures and water flow and a record of agreements between the "kumbini" government (East India Company) and the shareholders (miracidars) of the irrigated villages. Although the British were not satisfied that the Vellore mamul nammar met their engineering standards and desired that technical improvement be attempted, they greatly feared the avalanche of litigation that would accompany interference in custom (Copies of Tamil Water Mamulnammas in Vellore Taluk 1907). Translated details of mamul nammars for two large tanks were kindly supplied to me by K. Sivasubramaniyam of the Madras Institute of Development Studies.

${ }^{35}$ Such a right has, if anything, been more strongly asserted in post-independence and post-zamindari Sivaganga.

${ }^{36}$ It was not only irrigation works but also roads, railways, and other works that affected water rights and provoked conflict by modifying water flows across the catchments. 
gation systems were ill protected (cf. Agrawal and Ribot 2000). Continued "royal gifting" in effect produced not a set of domain holders (temples, Brahmans, bankers, or royal kin) symbolically and materially (through ritual honors and grain shares) integrated into the articulation of a warrior state, but a landscape of complex and insecure property rights and local authority cut loose from incentives or obligations to invest.

If authority could no longer constitute itself through public works, rural wealth no longer had to. As David Washbrook notes, writing about British south India more generally, secure property rights, bureaucratized revenue systems, and surplus labor eliminated the need for capital to be socially responsible: "In most areas rising peasant densities were making it possible to charge competitive rents and to enforce subsistence-debt contracts in relation to minimal expenditures of risk capital" (1988, 88). ${ }^{37} \mathrm{~A}$ surplus workforce and lower prices for labor as well as the need for cash to meet revenue demand and higher returns from usury gave the possessors of capital a capacity to expropriate an increasing share of resources from labor and producers (Washbrook 1988, 86-87).

Zamindar authority and the rule of water were further undermined by legal, engineering, and several other colonial interventions with indirect but profound effects. Firstly, British policy and infrastructure (roads and railways) opened up new markets that encouraged the expansion of cash cropping of chilies, cotton, and tobacco on previously uncultivated land after 1850. Especially on black cotton soils, farmers were abandoning share-based rice cultivation under tanks in favor of more profitable dryland cash crops on which a fixed-cash rent applied (Mosse 2003, 113-16). This not only seriously reduced resource flows to the zamindars but also disrupted a distinctive relationship between cultivators and the estate upon which zamindar authority and Maravar caste dominance rested (Mosse 2003, 113-16). The hierarchical relationships and identities that had evolved around tank-irrigated paddy and were ritualized at the threshing floor (where grain shares were divided) expressly acknowledged the superior right of the royal overlord and his or her control of the local redistribution system. Dryland cash cropping simplified economic relations and opened up space outside the moral structure of paddy cultivation and redistribution. The challenge to paddy cultivation as "the dominant idiom of power and hierarchy" (Spencer 1990, 107) had the further effect of weakening the authoritative institutions that operated tanks systems (see Mosse 1997b, 2003).

The zamindars made desperate but unsuccessful attempts to prohibit and penalize the cultivation of cash crops in place of paddy and to prohibit even the improvement of dryland for rain-fed farming so as to force farmers back into older revenue relationships based on tank-irrigated paddy cultivation. ${ }^{38}$ But, the Sivaganga estate's effort

\footnotetext{
${ }^{37}$ Washbrook in fact points out that the momentum of changes associated with British conquest was already "set up by the logic of indigenous capitalist development ... from the seventeenth century" by military fiscalism and "sultanist" regimes, which overrode redistributive systems of rule $(1988,88)$.

${ }^{38}$ In the case of cotton cultivation under sixteen tanks in Tiruppuvanam Taluk, the estate subdistrict revenue office recommended imposing tax (sarasari) on these lands to dissuade farmers from abandoning wet crops under tanks, which (soil permitting) the office sought to do. In addition to stiff taxes on dryland cash crops and wells, there was even a bund tax"varappukatti sarasari, and a tax on dryland with water-retaining ridges ("achukattu pinja") (TNSA, MELAC, Oral Evidence, pt. 4, p. 301; Sattappa Pillai vs Raman Chetti, Indian Law Reports, Madras Series vol. 17, January-December 1894 [thanks to Pamela Price for supplying this to me]; SSRO, "Note from Tahsildar Tiruppuvanam to The Manager of Court of Wards," Sivaganga, December 24, 1913).
} 
to impose additional crop-specific taxes on dryland cash crops was successfully challenged in the Madras High Court - especially where such crops were cultivated using wells dug by farmers themselves (TNSA, MELAC, Oral Evidence, pt. 4, pp. 306-7). Indeed, there was an unstoppable and wider shift in the economic focus of the countryside away from the estate office (the pinnacle of the hierarchical control of tank-based paddy cultivation) and toward railway-connected market towns (the centers for cashcrop production), which entailed the gradual loss of whatever grip the zamindar had on the estate's economy (Baker 1984).

Significantly, challenges to the old order of rule took place in both the rice fields and threshing floors and also the temples- the institutions that had such a key role in integrating warrior rule. Conflicts erupted at major regional temples as economically successful cash-crop cultivators (especially those of the Utaiyar caste) joined Chettiyar merchants in contesting festival honors held by Maravar headmen and chiefs. ${ }^{39}$ At the same time, the Maravar zamindars were losing the control that they themselves had over temples, since the British had also begun to intervene in temple administration or had appointed overseers "to see that the accustomed ceremonies of each pagoda are performed" (TNSA, R. Peter, collector, report on Settlement of Ramnad, February 5, 1816, Madurai District Records no. 9034, pp. 25ff.; see also Price 1996, 114). This was a second intervention that had implications for zamindari rule. Pamela Price discusses the loosening hold that the Ramnad raja had over the temple at Rameswaram. Similarly, the Sivaganga raja struggled through the courts to retain the right to superintendence and first honors at the Kalaiyarkoil temple against challenges from Nattukottai Chettiyars, whose increasingly important financial hold on the zamindari and its royal endowments also led them to insert themselves as major temple donors (SSRO, A. L. A. R. R. M. Arunachalam Cettiyar vs Zamindar of Sivaganga, suit no. 43, 1923, Court of the Additional Subordinate Judge of Sivaganga).

A third intervention was the British attempt to abolish the share revenue system. This may have been resisted in the short term (see above), but the effect of imposing harsh cash tax demands with the court-backed seizure of property against debt was to change the relationship between ryots and the estate. The simplification and abstraction of tax from existing social relations (in the context of disrupted resource flows into tank maintenance) terminally weakened the moral standing of the rajazamindars (cf. Mitchell 2002, 73). In the 1930s and 1940s, the refusal of rent was increasingly justified in terms of the moral failure of the zamindar "state" to maintain irrigation systems, which was the main theme at rallies and meetings organized in the 1940s under the Congress banner which called for zamindari abolition (Mosse 2003 , 119). By failing to ensure resource flows into the irrigation system, the rulers had abused their obligations and moral rights to grain shares. Older villagers in Alapuram clearly remember regular conflicts when estate officers would attempt to collect melvaram without repairing the tank: "Without cutting the tank, you came to take the "upper share'?" (kammāy veț̣āmal mèlvāram vānka vantinkaḷā?). To preempt conflict, the estate would rapidly organize superficial tank "repair" work, derisively referred to by villagers as "sweeping" the tank.

In sum, then, although patronage and segmentary authority created the semblance of continuity with an old decentralized state order, in fact the dispersal of resources

${ }^{39}$ In the temple at Nayanarkoil (as at Kalaiyarkoil), in addition to holding mantakapatisthat is, having the right to organize processions of the deity on particular festival daysUtaiyars acquired land grants for temple services, including those for the provision of straw for cattle at the annual festival. 
and authority and the contestation of rights and responsibilities worked against the reinvestment of resources into irrigation at every level. Political incentives to invest were not what they had been, tenures were insecure, and economic returns were extremely uncertain. Colonial zamindari rule had rearranged relations of power, weakening the Maravar rajas and the structures of devolved authority operating through the Maravar-controlled share revenue system, while giving new power to officers of the estate, Chettiyar bankers, commercial farmers, courts, and engineers. Meanwhile, a variety of interventions in property rights, water law, irrigation technology, revenue, markets, and temple administration weakened the moral framework of the rule of water.

Following Timothy Mitchell, my point is not that British rule imposed a new bureaucratic order or that its universal principles were "a new representation of existing realities" (a work of social imagination), but that colonial rule involved "new arrangements that would simplify the world into reality and its [representation]" $(2002,95)$. Through new arrangements ranging from private property to court decisions on water flows, masonry structures dividing water to cash cropping and fixed money taxes, simplifications and abstractions were effected that concealed underlying social complexity so as to enable "reason to rule" and allow actions to appear to be guided by the application of universal rational principles (the rule of law, property, revenue efficiency, or engineering science). This rule of reason would be sustained into postcolonial times by rearrangements that concentrated knowledge in new sites through cadastral surveys, irrigation records, topographical maps, and other measures that effected a separation between the ideal and the real. "Chain[s] of social practices" could now be experienced as "the distance between reality and its representation" (Mitchell 2002, 115). But while colonial rule was represented as the opposite of arbitrary power (which characterized antecedent regimes), its effects were in reality the outcome of now-erased arbitrariness, of hidden rearrangements of power achieved through military action, dispossession, coercion, control, and violence (Mitchell 2002, $4-5,77-78,91)$.

\section{Conclusions}

The story of colonial rule revealed in the transformation of the irrigation commons discussed here is not one in which imperial ideas of property, revenue, engineering science, or the rule of law are imposed as a state grid from outside (Scott 1998). Rather, British rule worked through a series of contingent interventions and compromises with past forms of kingly rule from which there was an incomplete break (cf. Mitchell 2002, 77). Among these interventions were the arbitrary judgments that framed local water rights through case law, the works of the engineering department that authorized particular water flows; the chaotic experiments in cash revenue and the violence against defaulters; the promotion of cash cropping (outside of the old system of redistribution); and the support of the most hybrid of all actors, the zamindar-rulers themselves. The messy reality in which these contingent interventions were made was one in which hybrid forms of rule existed, where the European legal distinction between the control over things (property) and the rule over people (sovereignty) was constantly being dissolved (cf. Mitchell 2002, 70); where the distinction between state and society, public and private, property and relationship, tax extraction and redistribution, sacred and secular, were blurred; where bankers could be rulers, property dispersed, and resources continuously circulated. From actions within this 
reality, rather than through systematic assertions of external bureaucratic control, new powers came into existence and a new distinction between state and society emerged (Mitchell 2002, 74). As Timothy Mitchell argues in the case of Egypt, schemes of political and technical control do not begin with the imposition of universal reason (the principles of property, revenue, engineering science, and law) on the reality of society. Instead, general principles such as property, tax, and law are ordering ideas that come out of a hybrid, unresolved, and mixed world of practice. He points out that "[i]deas and technology did not precede this mixture as pure forms of thought brought to bear upon the messy world of reality. They emerged from the mixture and were manufactured in the process themselves" (2002, 52), becoming legaladministrative principles of colonial government only after the event, shaped as representations increasingly apart from the complex political processes. He argues: "Instead of invoking the force and logic of reason, self-interest, science, or capital and attributing what happens in the world to the working of these enchanted powers and processes, we can open up the question ... of what kinds of hybrid agencies, connections, interactions, and forms of violence are able to portray their actions as history, as human experience overcoming nature, as the progress of reason and modernity, or the expansion and development of capitalism" (53).

British administrators may not have imposed the rational principles of property, for-profit investment, extractive revenue, or legally and technically ordered flows of water-in short, the rule of property, law, and order-but their "hybrid agencies, connections, interactions, and forms of violence" had a profound effect on the operation of existing systems of resource control, constantly setting up contradictions within them. One effect was, as David Washbrook (1976) notes, that under British rule the power of rural leaders came to be cut loose from a wider set of political relations with the state and was newly freed from the obligations of reciprocity and redistribution which had earlier been part of the social construction of authority. Just as zamindari rule had sought to maintain itself through largess and redistribution, so too was its collapse reflected in the failure to protect and invest in public assets (cf. Baker 1984, 436). This was itself the result of the contradictions of kingly rule under a colonial state. During the nineteenth century, the rajas no longer directed ritual systems of redistribution at key temples, whose devastanam lands were now under lease to Nattukottai Chettiyars; the virtual collapse of the irrigation infrastructure meant that their control over water and material systems of redistribution focusing on wetland paddy was weakened. While patterns of largess and redistribution continued to create local landed domains, the heads of these domains-among them Maravar heads of natus and villages - no longer seriously sought or received their political legitimacy and status from the rajas at Ramnad and Sivaganga (local big men were no longer the "raja's men") and turned to the courts, not the palaces, to secure irrigation rights. By the 1930s, they had organized to resist the demands of the estate; now local power had more to do with preventing the state from interfering in the locality than with identifying with its interests (see Washbrook 1976, 332). These political transformations had profoundly negative effects on the irrigated landscape of the southern plains, which were only amplified by British legal, administrative, and engineering interventions.

Beyond the confines of the zamindaris, by the end of the nineteenth century, the compromises and coercions, arbitrary actions, and struggles that colonial practice involved had become hidden behind the new order of British administrative control over irrigation through a centralized, professional public-works department. Bureaucratic and engineering principles were newly conceived of as an ideal, separate from 
the actual world in which they intervened (by an "engineering paradigm" in which irrigation was a mathematically modeled system which could be engineered to maximize water control, bounded and knowable, separate from society [Gilmartin 1995, 212]) (see Mitchell 2002, 77). The problem was that in producing this abstract world of bureaucratic intention separate from practice (in reorganizing power over people into power over space [Mitchell 2002, 90]), the social basis of irrigation management was itself undermined. That is to say, the government had written out the localized rights and the social control over labor on which its own irrigation administration actually depended. This precipitated a crisis. The government had brought the burden of maintaining tens of thousands of irrigation tanks upon itself, but there was no way that it could afford (or socially organize) the investment necessary to replace the disrupted systems of authority and decentralized investment in tanks. The denial of political power in the system and the irreversible separation of wealth/power from public investment were the price paid for having "neatly separate realms of reason and the real world, ideas and their objects..." (Mitchell 2002, 52).

The British response to this dilemma was not the political decentralization of the former kings and zamindars, but rather a characteristic "invention" of Indian village tradition - in this case, traditional village institutions of irrigation maintenance, which were desired and later compelled by law to try to maintain highly decentralized irrigation systems (Mosse 1999; 2003, 243-54). The ineffective and paradoxical idea of state-imposed traditional village institutions, established in the nineteenth century, set a mold for "community development" initiatives in irrigation which would persist for over a century, with repeated, often futile, efforts to devolve irrigation-maintenance responsibility onto water users through "traditional" institutions that were in decline from the moment that they came into existence (a story told elsewhere [see Mosse 2003]). Environmentalists misrepresent the effects of colonial state control as eroding (rather than inventing) village tradition. The focus both on the "Orientalized" lost village community and on colonial bureaucratic imposition diverts attention from complex underlying changes in the political systems in which tanks (and other common resources) were embedded, as well as the ruptures of British rule and the politics of representations of governance.

\section{List of References}

\section{Archival Sources}

Jesuit Madura Mission Archives (JMMA). Shembaganur, Tamil Nadu. Oriental and India Office Collections. British Library, London. Sivaganga Samastanam Record Office. Sivaganga, Tamil Nadu. Tamil Nadu State Archives. Egmore, Chennai.

\section{Other Sources}

Agarwal, Anil, and Sunita Narain. 1989. Towards Green Villages: A Strategy for Environmentally Sound and Participatory Rural Development. Delhi: Centre for Science and Environment.

\footnotetext{
, eds. 1997. Dying Wisdom: Rise, Fall, and Potential of India's Traditional Water Harvesting Systems. State of India's Environment, a Citizens' Report, no. 4. New Delhi: Centre for Science and Environment.
} 
Agrawal, Arun, and Jesse C. Ribot. 2000. "Accountability in Decentralization: A Framework with South Asian and West African Cases." Paper presented at the Colloquium on Decentralization and Development, Yale University, February.

Athreya, Venkatesh, Goran Djurfeldt, and Staffen Lindberg. 1990. Barriers Broken: Production Relations and Agrarian Change in Tamil Nadu. New Delhi; Newbury Park, Calif.; London: Sage Publications.

BAKer, C. J. 1984. An Indian Rural Economy, 1880-1955: The Tamilnad Countryside. Oxford: Clarendon Press.

Bandopadhyay, Arun. 1992. The Agrarian Economy of Tamilnadu, 1820-1855. Calcutta: K. P. Bagchi.

Breckenridge, Carol Appadurai. 1985. "Social Storage and the Extension of Agriculture in South India, 1350-1750." In Vijayanagara - City and Empire: New Currents of Research, ed. Anna Libera Dallapiccola. Stuttgart: Steiner Verlag Wiesbaden.

Copies of Tamil Water Mamulnammas in Vellore Taluk. 1907. Madras: Government Press.

Daniel, E. Valentine. 1984. Fluid Signs: Being a Person the Tamil Way. Berkeley and Los Angeles: University of California Press.

Davison-Jenkins, Dominic J. 1997. The Irrigation and Water Supply Systems of the Vijayanagara. New Delhi: Manohar; Chicago: American Institute of Indian Studies.

Dikshit, G. S, G. R. Kuppuswamy, and S. K. Mohan. 1993. Tank Irrigation in Karnataka: A Historical Survey. Bangalore: Gandhi Sahitya Sangha.

Dirks, Nicholas. 1986. "From Little King to Landlord: Property, Law, and Gift under the Madras Permanent Settlement." Comparative Studies in Society and History 28(2):307-33.

- 1987. The Hollow Crown: Ethnohistory of a South Indian Little Kingdom. Cambridge: Cambridge University Press.

Fuller, C. J., and John Harriss. 2000. "For an Anthropology of the Modern Indian State." In The Everyday State and Society in Modern India, ed. C. J. Fuller and Véronique Bénéi. New Delhi: Social Science Press.

Gadgil, Madhav, and Ramachandra Guha. 1992. This Fissured Land: An Ecological History of India. Delhi: Oxford University Press.

-1995. Ecology and Equity: The Use and Abuse of Nature in Contemporary India. London and New York: Routledge.

Government of Tamil Nadu. 1977. History of Land Revenue Settlement and Abolition of Intermediary Tenures in Tamil Nadu. Madras: Government of Tamil Nadu.

Heitzman, James. 1997. Gifts of Power: Lordship in an Early Indian State. Delhi: Oxford University Press.

Hirsch, ERIC. 1995. "Introduction-Landscape: Between Place and Space." In The Anthropology of Landscape: Perspectives on Place and Space, ed. Eric Hirsch and Michael O'Hanlon. Oxford: Clarendon Press.

Janakarajan, S. 1997. "Tank Institutions: Hidden Facts.” In Dying Wisdom: Rise, Fall, and Potential of India's Traditional Water Harvesting Systems, ed. Anil Agarwal and Sunita Narain. State of India's Environment, a Citizens' Report, no. 4. New Delhi: Centre for Science and Environment.

Kadhirvel, S. 1977. A History of the Maravars, 1700-1802. Madras: Madras Publishing House.

KAR ASHIMA, NOBORU. 1984. South Indian History and Society: Studies from Inscriptions, A.D. 850-1800. Delhi: Oxford University Press. 
Krishnaswamy, S. Y. 1947. Rural Problems in Madras. Madras: Superintendent, Government Press.

LARDinoIs, R. 1989. "Deserted Villages and Depopulation in Rural Tamil Nadu, c. 1780-c. 1830." In India's Historical Demography, ed. Tim Dyson. Richmond, Surrey: Curzon.

Leveil, L. M. 1937. "Le Maravar” [The Maravar]. Nuntii de Missionibus 7:441-46.

Li, Tania Murray. 1999. "Compromising Power: Development, Culture, and Rule in Indonesia." Cultural Antbropology 14(3):295-322.

- 2002. "Government through Community and the Practice of Politics." Paper presented at the Agrarian Studies Seminar, Yale University, October.

LudDen, DAvid. 1978. "Ecological Zones and the Cultural Economy of Irrigation in Southern Tamil Nadu." South Asia, n.s., 1(1):1-13.

- 1979. "Patronage and Irrigation in Tamil Nadu: A Long-Term View." Economic and Social History Review 16(3):347-65.

- 1985. Peasant History in South India. Princeton, N.J.: Princeton University Press.

Madsen, Stig Toft. 1999. State, Society, and Environment in South Asia. Richmond, Surrey: Curzon.

Mahé 1939. "Letter 'Alapuram.” Caritas 23:14-17.

Mitchell, Timothy. 2002. The Rule of Experts: Egypt, Techno-politics, Modernity. Berkeley and Los Angeles: University of California Press.

Mizushima, Tsukasa. 1986. Nattar and the Socio-economic Change in South India in the 18th-19th Centuries. Tokyo: Institute for the Study of Languages and Cultures of Asia and Africa, Tokyo University of Foreign Studies.

Mosse, David. 1986. "Caste, Christianity, and Hinduism: A Study of Social Organisation and Religion in Rural Ramnad.” DPhil diss., Oxford University.

- 1994. "The Politics of Religious Synthesis: Roman Catholicism and Hindu Village Society in Tamil Nadu, India." In Syncretism/Anti-syncretism: The Politics of Religious Synthesis, ed. Charles Stewart and Rosalind Shaw. London and New York: Routledge.

- 1997a. "Honour, Caste, and Conflict: The Ethnohistory of a Catholic Festival in Rural Tamil Nadu (1730-1990)." In Altérité et identité: Islam et christianisme en Inde [Otherness and Identity: Islam and Christianity in India], ed. J. Assayag and G. Tarabout. Paris: Editions de l'Ecole des Hautes Études en Sciences Sociales. . 1997b. "The Symbolic Making of a Common Property Resource: History, Ecology, and Locality in a Tank-Irrigated Landscape in South India." Development and Change 28(3):467-504.

. 1999. "Colonial and Contemporary Ideologies of Community Management: The Case of Tank Irrigation Development in South India." Modern Asian Studies 33(2):303-38.

- 2003. The Rule of Water: Statecraft, Ecology, and Collective Action in South India. New Delhi: Oxford University Press.

Narayana Rao, Velcheru, David Shulman, and Sanjay SubrahmanYAM. 1992. Symbols of Substance: Court and State in Nayaka Period Tamil Nadu. New Delhi: Oxford University Press.

Neale, Walter C. 1969. "Land Is to Rule." In Land Control and Social Structure in Indian History, ed. Robert E. Frykenberg. Madison: University of Wisconsin Press.

Nelson, J. H. 1868/1989. The Madura Country: A Manual. Pts. 3 and 4. Reprint, New Delhi: Asian Educational Services. 
Price, Pamela G. 1979a. "Rajadharma in Ramnad: Land Litigation and Largess." Contributions to Indian Sociology, n.s., 13(2):207-39.

- 1979b. "Resources and Rule in Zamindari South India, 1802-1903: Sivagangai and Ramnad as Kingdoms under the Raj." PhD diss., University of Wisconsin, Madison.

-1996. Kingship and Political Practice in Colonial India. Cambridge: Cambridge University Press.

Rajaram Row, T. 1891. Manual of the Ramnad Samastanam. Madurai: Cleghorn Press.

Rudner, David West. 1989. "Bankers' Trust and the Culture of Banking among Nattukottai Chettiars of Colonial South India." Modern Asian Studies 23(3):41758.

- 1994. Caste and Capitalism in Colonial India: The Nattukottai Chettiars. Berkeley and Los Angeles: University of California Press.

Scott, James. 1998. Seeing Like a State: How Certain Schemes to Improve the Human Condition Have Failed. New Haven, Conn.: Yale University Press.

Sengupta, Nirmal. 1993. User-Friendly Irrigation Designs. New Delhi: Sage Publications.

Shah, T., R. Seenivasan, C. R. Shanmigam, and M. P. Vasimalai. 1999. Sustaining Tamilnadu's Tanks: Fieldnotes on PRADAN's Work in Madurai and Ramnad. New Delhi: International Development Enterprises and Ford Foundation; Madurai: Dhan Foundation.

Sinha, Subir, Shubhra Gururani, and Brian Greenberg. 1998. "The 'New Traditionalist' Discourse of Indian Environmentalism." Journal of Peasant Studies 24(3):65-99.

Sivaramakrishnan, K. 1999. Modern Forests: Statemaking and Environmental Change in Colonial Eastern India. New Delhi: Oxford University Press.

Spencer, Jonathan. 1990. A Sinbala Village in a Time of Trouble: Politics and Change in Rural Sri Lanka. New Delhi: Oxford University Press.

Stein, Burton. 1960. "Economic Functions of a Medieval South Indian Temple." Journal of Asian Studies 19(2):163-76.

-1980. Peasant State Society in Medieval South India. New Delhi: Oxford University Press.

- 1985. "Politics, Peasants, and the Deconstruction of Feudalism in Medieval India." Journal of Peasant Studies 12(2-3):54-86.

Subbarayalu, Y. 1973. The Political Geography of the Chola Country from AD 800 to 1300 as Gleaned from Epigraphy and Literature. Madras: Madras University Press.

Sundar, Nandini. 2000. "Unpacking the 'Joint' in Joint Forest Management." Development and Change 31:255-79.

Thippaiah, P. 1998. "Status of Tank Irrigation in Karnataka." In Proceedings of the Consultative Workshop on Renovation in Rainfed Irrigation Tanks with Farmers' Involvement in Karnataka. Madurai: DHAN Foundation; Bangalore: Institute for Social and Economic Change.

Vaidy anathan, A. 1992. Strategy for Development of Tank Irrigation. Madras: Madras Institute of Development Studies.

von Oppen, M., and K. V. Subba Rao. 1980a. "Tank Irrigation in Semi-Arid Tropical India, Part 1: Historical Development and Spatial Distribution." Progress Report, no. 5, Economics Programme, International Crops Research Institute for the Semi-Arid Tropics. 
. 1980b. "Tank Irrigation in Semi-Arid Tropical India, Part 2: Technical Features and Economic Performance." Progress Report, no. 8, Economics Programme, International Crops Research Institute for the Semi-Arid Tropics.

W ashbrook, David. 1976. The Emergence of Provincial Politics: The Madras Presidency, 1870-1920. Cambridge: Cambridge University Press.

- 1988. "Progress and Problems: South Asian Economic and Social History, c. 1720-1860." Modern Asian Studies 22(1):57-96.

Winner, Langdon. 1999. "Do Artefacts Have Politics?" In The Social Shaping of Technology, ed. Donald MacKenzie and Judy Wajcman. 2nd ed. Buckingham: Open University Press. 